\title{
PENYAKIT HAWAR DAUN PINUS MERKUSII DI BERBAGAI PERSEMAIAN KAWASAN UTAMA HUTAN PINUS JAWA TIMUR
}

\author{
Sutarman \& Andriani Eko Prihatiningrum \\ Fakultas Pertanian Universitas Muhammadiyah Sidoarjo \\ Jl. Raya Gelam 250 Candi Sidoarjo, Jawa Timur, 61271 \\ E-mail: sutarman@umsida.co.id
}

\begin{abstract}
Leaf blight disease of Pinus merkusii in various nurseries of pine forest in major area of East Java. This study aims to: (i) obtain isolates of pathogens, (ii) determine disease on seedling growth during the critical period and the young plants, (iii) determine the effect of pathogenic isolates on disease severity, and (iv) determine the effect of altitude on severity of seedling's leaf blight disease of Pinus merkusii from various nursery locations in East Java. The experiment was conducted in February-August 2014 at nine locations in the nursery and one young pine plantation site. Disease index data were analyzed using Microsoft Office Excel 2007 software to determine the regression model of the relationship between the index of disease with the independent variables and with Anova followed by Duncan test to find out the effect of altitude difference to the index of disease. Pathogen that causes late blight is Pestalotia theae Sawada. In the critical period, seedling disease index increased from 7.38 to an average of 26.96 in the nursery RPH Celaket; while on the young plants in the field in RPH Kemiri disease index ranged 28-31. Differences in altitude did not affect disease index difference. Based on disease index, three isolates of pathogens that require serious attention are Wagir isolates ( $985 \mathrm{~m}$ asl., the most virulent), Ngantang (500 $\mathrm{m}$ asl.), and South Pujon (1200 m asl.).
\end{abstract}

Key words: altitude, disease index, Pestalotia theae, Pinus merkusii

\begin{abstract}
ABSTRAK
Penyakit hawar daun Pinus merkusii di berbagai persemaian kawasan utama hutan pinus Jawa Timur. Penelitian ini bertujuan untuk: (i) mendapatkan isolat patogen hawar daun, (ii) mengetahui pertumbuhan penyakit hawar daun pada bibit selama periode kritisnya dan pada tanaman muda, (iii) mengetahui pengaruh isolat patogen terhadap keparahan penyakit, dan (iv) mengetahui pengaruh ketinggian tempat terhadap keparahan penyakit hawar daun bibit Pinus merkusii dari berbagai lokasi persemaian di Jawa Timur. Penelitian dilaksanakan pada Februari-Agustus 2014 di 9 lokasi persemaian dan 1 lokasi pertanaman muda pinus. Data indeks penyakit dianalisis dengan menggunakan software Excel 2007 Microsoft Office untuk mengetahui model regresi hubungan antara indeks penyakit dengan variabel bebasnya dan dengan Anova yang dilanjutkan dengan uji Duncan untuk mengetahui pengaruh perbedaan ketinggian tempat terhadap indeks penyakit. Patogen yang menyebabkan hawar daun adalah Pestalotia theae Sawada. Dalam periode kritisnya, indeks penyakit bibit tumbuh dari 7,38 hingga mencapai rata-rata 26,96 di persemaian RPH Celaket; sedangkan pada tanaman muda di lapangan di RPH Kemiri indeks penyakit tidak tumbuh yaitu antara 28-31. Perbedaan ketinggian tidak mempengaruhi perbedaan indeks penyakit. Berdasarkan indeks penyakit, 3 isolat patogen yang memerlukan perhatian serius adalah isolat Wagir (985 m dpl.) yang paling virulen, diikuti oleh Ngantang (500 m dpl.) dan Pujon Selatan (1200 m dpl.).
\end{abstract}

Kata kunci: indeks penyakit, ketinggian tempat, Pestalotia theae, Pinus merkusii

\section{PENDAHULUAN}

Pinus merkusii adalah salah satu tumbuhan asli Indonesia dengan habitat asal di daerah antara Aceh dan Sumatera Utara yang penyebarannya ke wilayah lain di Sumatera (Jambi, Sumatera Barat, Lampung), Sulawesi, dan Jawa. Khusus di Jawa Timur pertanaman P. merkusii dikelola Perum Perhutani Unit II Jawa Timur, terletak di luar kawasan konservasi pegunungan: Welirang-Arjuna-Anjasmoro, Kawi dan Kelud, BromoTengger-Semeru, serta Iyang dan Ijen yang dapat dianggap sebagai kawasan utama hutan pinus di Jawa Timur.

Sejauh ini perhatian banyak pihak lebih tertuju pada fakta kerusakan hutan akibat degradasi lahan dan hutan yang sebagian besar disebabkan oleh aktivitas 
manusia dan perubahan iklim. Sementara itu perhatian terhadap ancaman laten gangguan organisme patogen sangat kurang. Khusus pada pinus di Indonesia, ada 2 jenis penelitian yang sudah dilakukan yaitu: oleh Achmad et al. (1997, 1999a, 1999b) terhadap penyakit damping off dengan output berupa informasi potensi agensia biokontrol dan oleh Sutarman et al. (2001, 2004a, 2004b) pada hawar daun bibit pinus yang menunjukkan fakta potensi Pestalotia theae sebagai patogen virulen. Dengan keterbatasan informasi dalam pola pembinaan hutan tanaman yang ada, maka tidak dapat dijamin pihak pemangku kepentingan dapat mengantisipasi ketika terjadi out break gangguan patogen yang bersinergi dengan dampak perubahan iklim.

Perubahan iklim dalam 2-3 dasawarsa terakhir diduga berperan dalam meningkatkan virulensi $P$. theae pada pinus. Di persemaian, konidiospora $P$. theae dipindahkan dari tanah media tanam yang berasal dari top soil bawah tegakan pinus melalui percikan air hujan dan penyiraman (Sutarman et al., 2004a). Patogen ini juga mampu menginfeksi dan menjadikannya inang alternatif tanaman pinus dewasa dan berbagai tanaman kehutanan lainnya baik pada tingkat pohon di alam maupun anakan (Canon, 1997; Old, 1997; Sharma \& Florence, 1997). Di lain pihak, bibit pinus meskipun memiliki simbiosis dengan mikoriza yang sempurna, diberi nutrisi/pupuk yang lengkap, dan dilindungi dengan aplikasi fungisida berbahan aktif mankozeb dan difenokonazol di persemaian ternyata tidak mampu menghambat serangan patogen hawar daun (Sutarman et al., 2001).

Penyakit hawar daun mulai menyerang pasca damping off dengan gejala penyakit mulai tampak jelas sejak bibit umur 2 bulan setelah overspin (BSO) dan berkembang pesat hingga bibit umur sekitar 6 BSO (Sutarman et al., 2001). Selain lama penyinaran matahari, seperti hasil penelitian Sutarman et al. (2004b) di Jawa Barat, ketinggian tempat mempengaruhi indeks penyakit. Namun demikian belum ada informasi seberapa jauh isolat patogen dari lokasi yang berbeda dengan ketinggian tempat yang berbeda berpengaruh terhadap kemunculan dan pertumbuhan tingkat infeksi penyakit yang ditimbulkannya.

Dari uraian tersebut di atas, kiranya sangat penting melakukan pengamatan status infeksi atau intensitas penyakit hawar daun bibit pinus ini pada berbagai kawasan representasi geoekologi dan pada beberapa ketinggian lokasi persemaian di berbagai kawasan utama hutan pinus di Jawa Timur. Seluruh data hasil penelitian diharapkan akan memperkaya informasi dalam rangka merancang strategi pengendalian penyakit hawar daun yang berpotensi mengancam eksistensi hutan pinus di
Jawa Timur khususnya dan di Indonesia atau di kawasan lain di mana ditumbuhkan P. merkusii.

Penelitian ini bertujuan untuk: (i) mendapatkan isolat patogen hawar daun, (ii) mengetahui pertumbuhan penyakit hawar daun pada bibit selama periode kritisnya dan pada tanaman muda, (iii) mengetahui pengaruh isolat patogen terhadap keparahan penyakit, dan (iv) mengetahui pengaruh ketinggian tempat terhadap keparahan penyakit penyakit hawar daun bibit $P$. merkusii dari berbagai lokasi persemaian yang menjadi representasi geoekologis.

\section{METODE PENELITIAN}

Tempat dan Waktu. Pelaksanaan penelitian terutama untuk isolasi dan pengamatan mikroskopis dilaksanakan di Laboratorium Mikrobiologi Pertanian, Program Studi Agroteknologi, Fakultas Pertanian Universitas Muhammadiyah Sidoarjo. Untuk pengamatan gejala, indeks penyakit, dan pertumbuhan penyakit, serta pengambilan contoh bibit pinus dilakukan di: (i) persemaian Resort Pemangkuan Hutan (RPH) Celaket, di bawah koordinasi Bagian Kesatuan Pemangkuan Hutan (BKPH) Pacet, sebagai satu-satunya persemaian yang melayani Kesatuan Pemangkuan Hutan (KPH) Pasuruan dan pertanaman pinus tahun tanam 2013 di RPH Kemiri yang dianggap mewakili kawasan geografis-ekologis pegunungan Arjuno-WelirangAnjasmoro, (ii) RPH Pujon Selatan, RPH Tumpang, RPH Bambang Utara-Dampit, RPH Ngantang, RPH Wagir-Kepanjen, RPH Sumberawan yang melayani KPH Malang dan dianggap mewakili kawasan geoekologis pegunungan Tenggar (Bromo-TenggerSemeru), dan (iii) RPH Garahan (Jember) dan RPH Wringin Tapung (Bondowoso) yang melayani KPH Jember dan KPH Bondowoso sekaligus mewakili kawasan geoekologis pegunungan Iyang dan Pegunungan Ijen. Penelitian dilaksanakan mulai Februari-Agustus 2014. Secara keseluruhan diamati 9 lokasi persemaian dan 1 lokasi pertanaman muda pinus tahun tanam 2013 yang bibitnya berasal dari produksi tahun 2013.

Isolasi dan Pengamatan Isolat Patogen. Daun jarum bibit $P$. merkusii bergejala hawar, yang diambil dari 9 lokasi persemaian dan 1 lokasi pertanaman (RPH Kemiri), dipotong dengan ukuran $\pm 5 \mathrm{~mm}$ dan disterilkan permukaannya dengan alkohol $50 \%$ selama 3 detik dan dibilas dengan air destilat steril. Selanjutnya potongan daun diinkubasi pada media PDA (komposisi media per liter: ekstrak kentang $200 \mathrm{~g}$, dekstrosa $20 \mathrm{~g}$, agar $20 \mathrm{~g}$, 
0,25 g chloramphenicol) pada suhu kamar. Pertumbuhan hifa serta karakteristik morfologi koloni dan konidiospora patogen diamati di bawah mikroskop cahaya merk "Yazumi" pada perbesaran 400 kali.

Pertumbuhan Indeks Penyakit. Untuk mengetahui pola pertumbuhan indeks penyakit hawar daun bibit $P$. merkusii pada periode kritis bibit dalam menghadapi infeksi penyakit yaitu ketika berumur 2-6 bulan setelah overspin (Sutarman et al., 2001 \& 2004a), maka dilakukan pengamatan pertumbuhan penyakit pada lokasi yang dapat merepresentasikan keseluruhan persemaian di Jawa Timur yaitu di RPH Celaket (Mojokerto, KPH Pasuruan). Untuk mengetahui pola pertumbuhan penyakit hawar daun pada tanaman muda pasca penanaman di lapangan, yang bibitnya berasal dari persemaian di RPH Celaket, dilakukan pengamatan di RPH Kemiri (Mojokerto, KPH Pasuruan) pada lahan seluas 2 ha. Pengamatan perkembangan penyakit pada persemaian dilakukan 4 kali dengan mengukur indeks penyakit bibit pinus umur $8,9,10,11$ dan 12 minggu setelah overspin (MSO) pada pengamatan pertama hingga bibit berumur 24-28 MSO (atau umur bibit 5-6 bulan). Pengamatan perkembangan penyakit pada tanaman muda (berasal dari bibit produksi 2013) di pertanaman dilakukan dengan mengukur indeks penyakit pada umur 9 dan 10 bulan setelah tanam. Indeks penyakit ditentukan dengan menggunakan rumus dan kriteria seperti yang disampaikan Sutarman et al. (2001) yang dimodifikasi:

$$
\mathrm{IP}=\frac{\sum_{\mathrm{i}=1}^{\mathrm{k}=4}\left(\mathrm{in}_{\mathrm{i}}\right)}{\mathrm{N} \cdot \mathrm{k}} \times 100 \%
$$

dengan:

$\mathrm{P}=$ Indeks penyakit

$\mathrm{i}=$ nilai numerik (skor) bibit dan/atau tanaman muda dengan kriteria gejala serangan yang bersangkutan $\mathrm{n}_{\mathrm{i}}=$ jumlah bibit dan/atau tanaman muda dengan kriteria gejala serangan yang bersangkutan

$\mathrm{N}=$ jumlah bibit dan/atau tanaman muda yang diamati

$\mathrm{k}=$ nilai numerik (skor) tertinggi dengan kriteria gejala serangan terberat

Penentuan skor gejala hawar daun tiap bibit dan/ atau tanaman muda yang diamati ditentukan dengan kriteria gejala seperti terlihat pada Tabel 1.

Indeks Penyakit di Berbagai Ketinggian Tempat. Pengamatan indeks penyakit hawar daun pada: (i) bibit pinus produksi tahun 2014 pada usia awal 8-12 MSO hingga berumur 21-25 MSO (atau berumur antara 5-6 bulan) yang merupakan periode kritis bibit pinus (Sutarman et al., 2001) pada semua lokasi persemaian, dan (ii) tanaman muda pinus yang berasal dari bibit produksi tahun 2013 pada persemaian di RPH Pujon Selatan dan RPH Wagir-Kepanjen (KPH Malang), RPH Celaket (KPH Pasuruan), RPH Garahan (KPH Jember), serta tanaman muda tahun tanam 2013 di RPH Kemiri (KPH Pasuruan).

Rancangan dan Analisis Statistika. Pertumbuhan indeks penyakit pada periode kritis (umur bibit antara 2-6 bulan) (di persemaian RPH Celaket) diukur dengan menghitung indeks penyakit bibit dengan kelompok umur awal bibit 8-12 MSO sebanyak 4 kali dengan jeda waktu 4 minggu, sehingga seluruhnya diperoleh 84 satuan pengamatan. Untuk pertumbuhan indeks penyakit pada

Tabel 1. Kriteria gejala hawar daun bibit dan/atau tanaman P. merkusii yang disebabkan oleh P. theae (modifikasi Sutarman et al., 2001)

\begin{tabular}{cl}
\hline Skor & \multicolumn{1}{c}{ Kriteria gejala } \\
\hline 0 & Tidak ada gejala hawar daun \\
1 & Sampai $1 / 3$ bagian tajuk dengan ujung-ujung dan/atau bagian tengah daunnya menguning \\
2 & $\begin{array}{l}\text { Antara } 1 / 3-2 / 3 \text { bagian tajuk dengan ujung-ujung dan/atau bagian tengah daunnya menguning } \\
\text { dan/atau sampai } 1 / 3 \text { bagian tajuk dengan ujung-ujung dan/atau bagian tengah daunnya coklat } \\
\text { mengering }\end{array}$ \\
3 & $\begin{array}{l}\text { Lebih dari } 2 / 3 \text { bagian tajuk dengan ujung-ujung dan/atau bagian tengah daunnya menguning } \\
\text { dan/atau sampai } 1 / 3-2 / 3 \text { bagian tajuk dengan ujung-ujung dan/atau bagian tengah daunnya coklat } \\
\text { mengering }\end{array}$ \\
& Lebih dari 2/3 bagian tajuk dengan daun-daun coklat mengering hingga tanaman mati \\
\hline
\end{tabular}


tanaman muda di lahan hutan pinus (RPH Kemiri) diukur dengan menghitung indeks penyakit tanaman muda pada 5 kelompok tanaman sebanyak 2 kali dengan jeda waktu 1 bulan, sehingga diperoleh 10 satuan pengamatan. Terhadap masing-masing data pertumbuhan indeks penyakit dilakukan penghitungan, untuk mendapatkan model regresi yang menghubungkan antara indeks penyakit dan waktu selama periode kritis (bibit di persemaian) dan di pertanaman muda pinus, dengan menggunakan software program Excel 2007-Microsoft Office dengan taraf nyata 5\%. Pada pengamatan indeks penyakit bibit produksi tahun 2014, untuk tiap lokasi dari 9 persemaian ditentukan secara acak 5 bedeng persemaian sebagai ulangan dengan umur bibit yang relatif seragam yaitu 24 MSO. Pengamatan indeks penyakit pada bibit produksi 2013 (4 lokasi persemaian dan 1 lokasi pertanaman tanaman muda) ditentukan secara acak 5 bedeng (untuk tiap persemaian) yang masing-masing mengandung 500-1000 bibit dan 5 "petak" (untuk pertanaman tanaman muda) yang masing-masing berukuran $2000 \mathrm{~m}^{2}$ (dengan jarak tanam $2 \times 3 \mathrm{~m}$ terkandung 260 batang tanaman per "petak"). Untuk tiap satuan pengamatan, indeks penyakit ditentukan dari 100 bibit dan/atau tanaman muda yang diamati dengan menggunakan rumus. Semua data indeks penyakit dianalisis dengan menggunakan ANOVA yang dilanjutkan dengan uji Duncan pada taraf 5\%.

\section{HASIL DAN PEMBAHASAN}

Hasil Isolasi Patogen. Hasil isolasi yang dilakukan dari daun bibit pinus bergejala hawar dari 9 lokasi persemaian dan dari daun tanaman berumur 9 bulan setelah tanam di RPH Kemiri menunjukkan patogen yang menyerang adalah Pestalotia theae Sawada dengan morfologi kondiospora dan koloni seperti tertera pada Gambar 1. Isolasi juga dilakukan dari daun (daun jarum, kotiledon, dan daun tunggal) yang belum menunjukkan gejala dengan kriteria seperti pada Tabel 1 dilakukan untuk mengetahui kemungkinan adanya fungi endofitik.

Koloni $P$. theae agak tipis di bagian tepi dan berwarna putih dengan miselium yang relatif lebih lebat di bagian tengah; tampak adanya zonasi pertumbuhan yang pola lingkarnya seperti lingkar tepi koloni. Pada bagian tengah tampak adanya aservuli yaitu massa berbentuk bintik-bintik berwarna hitam yang merupakan massa padat kumpulan konidiospora dengan diameter beragam antara 0,5-1,5 mm. Konidiospora dari 10 isolat yang ditemukan dari penelitian ini menunjukkan bentuk dan ukuran yang relatif sama. Tiap konidiospora patogen terdiri atas lima sel yang berjajar lurus sampai melengkung (Gambar 1). Sel paling pangkal (sel apikal) berwarna hialin dilengkapi dengan setula hialin yang berjumlah 2-3 helai dengan posisi agak melengkung ke dalam; sel urutan ke-2 dan 3 dari ujung berwarna coklat gelap, sedangkan sel urutan ke 4 berwarna coklat namun tidak segelap sel ke-2 dan 3; sel ke-5 (sel basal) agak silindrik dan hialin yang dilengkapi dengan pedisel (tangkai konidia). Konidiospora berukuran rata-rata $24,35 \mu \mathrm{m} \times 7,23 \mu \mathrm{m}$, sedangkan panjang rata-rata setula $32,85 \mu \mathrm{m}$ dan pedisel $8,55 \mu \mathrm{m}$.

Semua ciri morfologi kesepuluh isolat $P$. theae dari berbagai lokasi di Jawa Timur ini sesuai dengan deskripsi patogen hawar daun bibit di Cianjur (Jawa Barat) (Sutarman et al., 2004b) yang menunjukkan bahwa jenis patogen ini adalah $P$. theae Sawada. Diperlukan penelitian lebih lanjut apakah ada penyebaran patogen hawar daun ini, yang berperilaku seperti patogen soil borne, dari suatu daerah ke daerah lain di pulau Jawa seperti pada kasus migrasi Phytophthora ramorum yang menyebabkan kematian tanaman oak dan kayu ornament (Goss et al., 2011). Sementara itu hasil isolasi terhadap daun yang belum menunjukkan gejala juga ditemukan patogen yang sama namun demikian fakta tersebut tidak mengindikasikan adanya $P$. theae endofitik seperti yang ditunjukkan Verticillium dahliae endofit mengkolonisasi inang namun tanpa menghasilkan gejala (Malcolm et al., 2013). Pada kasus hawar daun bibit Pinus banksiana dan P. resinosa, gejala ditentukan oleh antagonisme Diplodia scrobiculata dan $D$. pinea di mana gejala hawar yang disebabkan oleh $D$. pinea yang berada bersama-sama dengan $D$. scrobiculata lebih rendah intensitas lukanya dibandingkan gejala hawar pada luka yang hanya ditempati D. pinea (Santamaría et al., 2011). Ditemukannya konidiospora $P$. theae dengan jumlah setula 3 helai di antara kumpulan konidiospora yang umumnya bersetula 2 helai menurut Sutarman et al. (2001; 2004b) merupakan variasi dari satu spesies $P$. theae dengan karakter patogenistik yang sama.

Pengamatan Pertumbuhan Indeks Penyakit. Hasil pengamatan pertumbuhan indeks penyakit bibit pinus di persemaian RPH Claket pada kelompok bibit berumur antara 8-12 MSO pada pengamatan pertama hingga 13 minggu berikutnya dapat dilihat pada Tabel 2 dan Gambar 2.

Hasil analisis regresi menunjukkan penambahan waktu pada umur awal bibit yang berbeda berpengaruh terhadap pertumbuhan indeks penyakit yang ditunjukkan dengan pola pertumbuhan indeks penyakit yang relatif sama antar umur awal bibit dengan model regresi: $\mathrm{Y}=$ $9,848+1,573 X_{1}-0,207 X_{2}$, di mana $X_{1}$ adalah waktu 

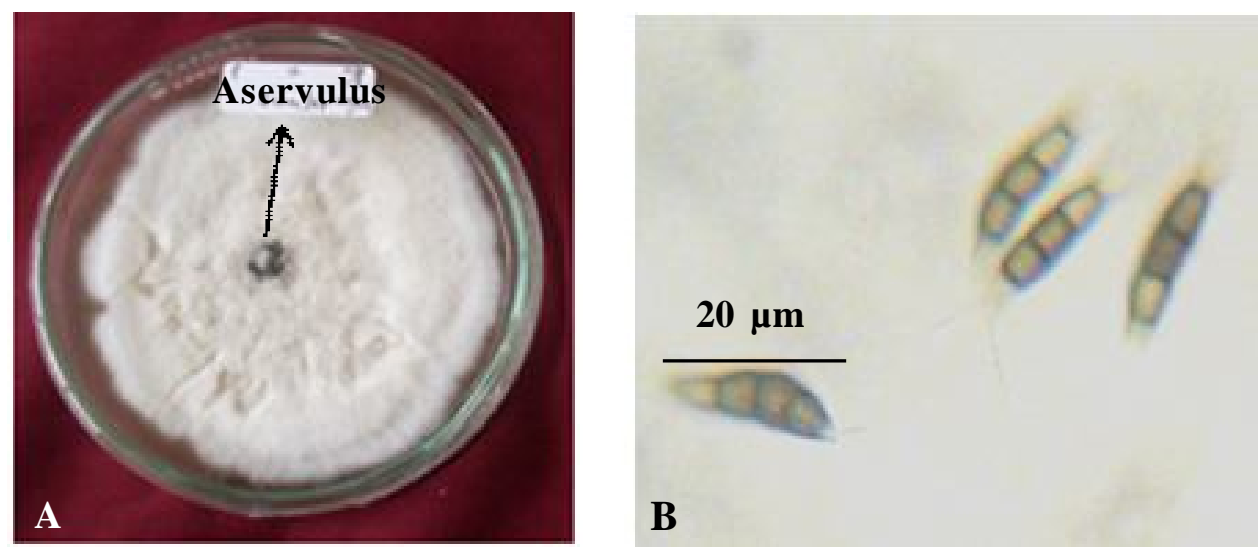

Gambar 1. Bentuk koloni (A) dan konidiospora Pestalotia theae Sawada (B)

Tabel 2. Indeks penyakit hawar daun bibit P. merkusii di RPH Celaket, BKPH Pacet, KPH Pasuruan

\begin{tabular}{ccccc}
\hline \multirow{2}{*}{ Kelompok umur bibit $^{1)}$} & \multicolumn{4}{c}{ Indeks penyakit (skala 0-100) ${ }^{2)}$} \\
\cline { 2 - 5 } & Minggu ke-1 & Minggu ke-5 & Minggu ke-9 & Minggu ke-13 \\
\hline 12 MSO & 7,38 & 11,40 & 19,53 & 27,61 \\
11 MSO & 9,09 & 11,24 & 21,23 & 27,39 \\
10 MSO & 9,45 & 13,54 & 20,76 & 26,86 \\
9 MSO & 9,59 & 13,51 & 20,44 & 26,39 \\
8 MSO & 8,42 & 12,93 & 20,47 & 26,55 \\
\hline Rata-rata & 8,78 & 12,52 & 20,49 & 26,96 \\
\hline
\end{tabular}

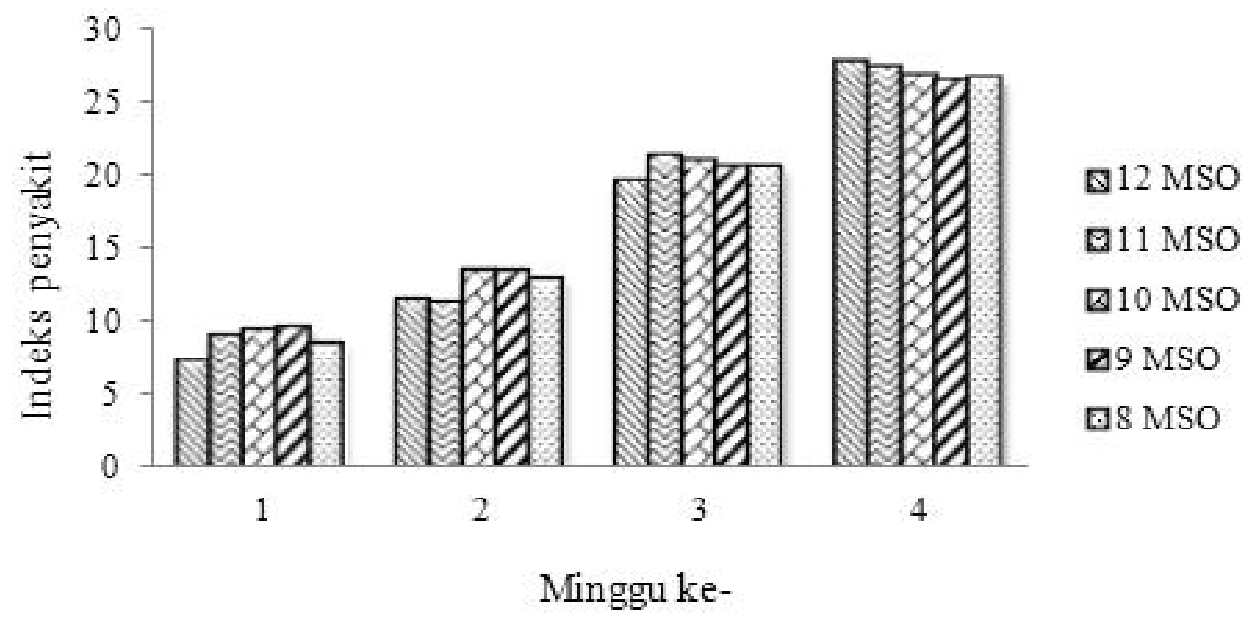

Gambar 2. Pertumbuhan indeks penyakit beberapa kelompok umur pada periode kritis bibit di RPH Celaket, BKPH Pacet, KPH Pasuruan 
pengamatan, $\mathrm{X}_{2}$ adalah umur awal bibit, dengan $\mathrm{R}^{2}=$ 0,941 (Tabel 3). Dengan demikian model regresi dapat diterima untuk menentukan indeks penyakit berdasarkan penambahan waktu dalam periode kritis bibit (umur 2-6 bulan) dengan umur awal pengamatan 8-12 MSO. Dalam model tersebut tampak bahwa variabel waktu (dalam periode kritis bibit) berpengaruh nyata terhadap pertambahan indeks penyakit ( $t$ stat 35,839; P-value 0,000 ) (Tabel 3). Sementara itu umur awal bibit dalam penelitian ini tidak berpengaruh nyata terhadap pertumbuhan indeks penyakit ( $t$ stat -1,471; P-value $0,145)$.

Hasil pengamatan perkembangan penyakit tanaman muda di RPH Kemiri dilakukan sebanyak 2 kali yaitu pada saat umur 9 bulan sampai umur 10 bulan setelah tanam disajikan pada Tabel 4. Pada tanaman muda tidak terdapat pertumbuhan yang nyata. Hasil analisis regresi menunjukkan penambahan waktu tidak berpengaruh terhadap pertumbuhan indeks penyakit $(\mathrm{t}$ hitung 0,65 dan $P$-value 0,53 pada koefisien regresi; significance $F$ 0,53 dan $\mathrm{R}^{2} 0,05$ pada ANOVA).

Sejalan dengan pertambahan umur bibit, indeks penyakit makin meningkat (Tabel 1, Gambar 2); makin bertambah usia bibit, maka jarak tajuk antar bibit makin mendekat dan tumpang-tindih pada umur mulai 4-5 bulan. Kepadatan tajuk yang tinggi, seperti dikemukakan Moral et al. (2012), merupakan penyebab perkembangan keparahan penyakit antraknosa lebih cepat pada tanaman zaitun yang disebabkan oleh Colletotrichum acutatum.

Di lain pihak tampak bahwa semua bibit dengan umur awal berbeda mengalami perkembangan indeks penyakit yang relatif sama dan pada akhir fase kritis, yaitu pada saat umur 5-6 bulan, indeks penyakit menjadi kurang dari 30 (26,39-27,61). Bibit umur 5-6 bulan dengan indeks penyakit di sekitar 25-30 ini relatif aman dari ancaman kematian, sehingga ketika umur 10-12 bulan bibit dapat dikirim ke lapangan untuk penanaman dan akan menjadi tanaman muda dengan indeks penyakit yang ringan seperti di RPH Kemiri (Tabel 4); akan tetapi untuk bibit dengan indeks penyakit yang lebih besar terutama di atas 50 pada saat bibit berumur 5-6 bulan, maka dapat dipastikan bibit mengalami kematian menjelang dan pasca penanaman di lapangan (Sutarman et al., $2001 \& 2004$ b).

Tabel 3. Koefisien regresi indeks penyakit hawar daun bibit $P$. merkusii pada periode kritis bibit di RPH Celaket, BKPH Pacet, KPH Pasuruan

\begin{tabular}{ccccccc}
\hline & Coefficients & Standard Error & $t$ Stat & P-value & Lower 95\% & Upper 95\% \\
\hline Intercept & 9,848 & 1,482 & 6,647 & 0,000 & 6,900 & 12,796 \\
Waktu & 1,572 & 0,044 & $\left.35,839^{*}\right)$ & 0,000 & 1,485 & 1,660 \\
Umur Awal & $-0,207$ & 0,141 & $-1,471$ & 0,145 & $-0,488$ & 0,073 \\
\hline
\end{tabular}

*) nyata pada taraf signifikansi $5 \%$.

Tabel 4. Indeks penyakit hawar daun pada tanaman muda P. merkusii di RPH Kemiri, BKPH Pacet, KPH Pasuruan (700 m dpl)

\begin{tabular}{ccc}
\hline \multirow{2}{*}{ Kelompok Tanaman $^{1)}$} & \multicolumn{2}{c}{ Indeks Penyakit (skala 0-100) } \\
\cline { 2 - 3 } & Pengamatan ke-1 & Pengamatan ke-2 ${ }^{2)}$ \\
\hline Petak 1 & 30,56 & 30,26 \\
Petak 2 & 28,57 & 28,57 \\
Petak 3 & 30,00 & 30,68 \\
Petak 4 & 28,13 & 29,55 \\
Petak 5 & 29,28 & 29,37 \\
Rata-rata & 29,31 & 29,69 \\
\hline
\end{tabular}

${ }^{1)}$ Petak tanaman menunjukkan sub lokasi yang berbeda graduasi lahan dengan umur tanaman sama yaitu 9 bulan setelah tanam, ${ }^{2}$ Waktu pengamatan berselisih waktu 1 bulan. 
Indeks Penyakit Hawar Daun Bibit Produksi 2014. Hasil analisis ragam (ANOVA 5\%: F hitung $(9,09)>\mathrm{F}$ Tabel $(2,21), \mathrm{db}: 8,36)$ menunjukkan adanya perbedaan indeks penyakit, yang menunjukkan derajat serangan, di antara lokasi persemaian yang diamati. Rerata indeks penyakit untuk masing-masing lokasi persemaian dapat dilihat pada Tabel 5.

Dari Tabel 5 tampak bahwa bibit pinus di Bambang Utara memiliki indeks penyakit rata-rata terkecil $(25,47)$, sementara itu bibit di Sumberawan, Tumpang, Celaket, Garahan, Pujon Selatan, dan Wringin Tapung relatif menunjukkan tingkat serangan penyakit yang lebih berat meskipun berada pada kisaran indeks penyakit (kurang dari 30) yang belum mengancam kematian bibit. Di lain pihak pada bibit di Wagir dan Ngantang kondisinya mengkhawatirkan karena berada pada kisaran indeks sekitar 50 yang dapat mengancam kematian bagi sebagian bibit ketika berumur 10 bulan hingga siap tanam. Fakta tersebut juga menjadi indikasi bahwa ada perbedaan virulensi di antara kesembilan isolat dari 4 kawasan representasi ekogeologis di Jawa Timur. Namun demikian ketinggian tempat yang menurut Sutarman et al. (2004a), berdasarkan penelitiannya di Jawa Barat menentukan berat serangan, ternyata pada pengamatan ini bukan penentu perbedaan indeks penyakit. Pada ketinggian yang relatif sama, indeks penyakit di Ngantang $(40,45)$ jauh lebih tinggi daripada di Tumpang $(29,06)$. Indeks penyakit yang berbeda di antara lokasi yang berbeda menunjukkan bahwa virulensi antar isolat relatif berbeda. $P$. theae isolat Wagir tampaknya paling virulen dibandingkan isolat lainya.

Selain virulensi isolat, curah hujan (Sutarman et al., 2004a) dan durasi kebasahan daun yang berbeda di antara lokasi persemaian menentukan adanya perbedaan indeks penyakit. Hasil penelitian Guyader et al. (2013) menunjukkan bahwa suhu (di antara 18-36) dan durasi kebasahan menentukan berat penyakit antraknosa pada Dioscorea alata yang disebabkan oleh Colletotrichum gleosporioides; pada daerah luka, aservuli berkembang dan menghasilkan konidiospora yang disebarkan ke permukaan daun di sekitarnya melalui percikan air hujan.

\section{Indeks Penyakit Hawar Daun Tanaman Muda}

Produksi 2013. Indeks penyakit hawar daun tanaman muda yang berasal dari bibit yang diproduksi tahun 2013 dari 4 lokasi persemaian dan 1 lokasi pertanaman tanaman muda menunjukkan derajat serangan yang berbeda berdasarkan hasil analisis ragam (ANOVA, $F$ hitung $(365,9)>$ F Tabel $(2,87)$, db: 4,20). Rerata indeks penyakit untuk masing-masing lokasi pengamatan tersaji pada Tabel 6.

Patogen isolat Wagir menunjukkan virulensi yang lebih tinggi dibandingkan dengan isolat lainnya berdasarkan hasil pengamatan terhadap bibit produksi

Tabel 5. Rerata indeks penyakit bibit tahun produksi 2014 pada berbagai persemaian P. merkusii di Jawa Timur dengan representasi geoekologis dan cakupan wilayah administrasi yang dilayaninya

\begin{tabular}{|c|c|c|c|c|c|}
\hline $\begin{array}{l}\text { Representasi } \\
\text { Geoekologis }\end{array}$ & $\begin{array}{l}\mathrm{KPH} \text { dan cakupan } \\
\text { wilayah adminstratif }\end{array}$ & $\begin{array}{c}\text { Lokasi pengamatan } \\
(\mathrm{RPH})\end{array}$ & $\begin{array}{l}\text { Altitude } \\
\text { (m dpl.) }\end{array}$ & $\begin{array}{l}\text { Rerata } \\
\text { indeks } \\
\text { penyakit }\end{array}$ & $\begin{array}{c}\text { Nilai } \\
\text { Duncan }\end{array}$ \\
\hline \multirow{6}{*}{$\begin{array}{l}\text { Pegunungan Welirang- } \\
\text { Arjuno-Anjasmoro } \\
\text { bagian Selatan, }\end{array}$} & \multirow{6}{*}{$\begin{array}{l}\text { KPH Malang } \\
\text { (Malang, Pasuruan, } \\
\text { Kediri, Blitar, } \\
\text { Lumajang) }\end{array}$} & Pujon Selatan & 1200 & $37,18 \quad b$ & 3,43 \\
\hline & & Sumberawan & 1045 & $28,06 \mathrm{~cd}$ & 4,12 \\
\hline & & Wagir & 985 & 50,33 a & 55 \\
\hline & & Bambang Utara & 680 & $25,47 \mathrm{~d}$ & 4,55 \\
\hline & & Tumpang & 520 & $29,06 \mathrm{~d}$ & 4,85 \\
\hline & & Ngantang & 500 & $40,45 \quad b$ & 5,08 \\
\hline \multirow{3}{*}{$\begin{array}{l}\text { Pegunungan Welirang- } \\
\text { Arjuno-Anjasmoro }\end{array}$} & & Celaket & 1040 & $27,72 \mathrm{~cd}$ & 5,27 \\
\hline & & & & & 5,43 \\
\hline & & & & & 5,57 \\
\hline $\begin{array}{l}\text { Gunung Iyang dan } \\
\text { sekitarnya }\end{array}$ & & Garahan & 540 & $28,99 \mathrm{~cd}$ & \\
\hline $\begin{array}{l}\text { Gunung Ijen dan } \\
\text { sekitarnya }\end{array}$ & & Wringin Tapung & 340 & $31,89 \mathrm{c}$ & \\
\hline
\end{tabular}

Angka-angka yang diikuti oleh huruf yang sama pada kolom yang sama menunjukkan perbedaan pengaruh yang nyata berdasarkan uji Duncan taraf 5\%. 
Tabel 6. Rerata indeks penyakit bibit tahun produksi 2013 pada berbagai persemaian $P$. merkusii dan tanaman pinus dengan tahun tanam 2013 di Jawa Timur

\begin{tabular}{lccc}
\hline \multicolumn{1}{c}{ Lokasi pengamatan } & $\begin{array}{c}\text { Altitude } \\
\text { (m dpl.) }\end{array}$ & $\begin{array}{c}\text { Rerata Indeks } \\
\text { Penyakit }\end{array}$ & Nilai Duncan \\
\hline Persemaian RPH Pujon Selatan (KPH Malang) & 1200 & 58,31 a & 1,28 \\
Persemaian RPH Wagir (KPH Malang) & 985 & $42,07 \mathrm{~b}$ & 1,48 \\
Persemaian RPH Celaket (KPH Pasuruan) & 1040 & $27,11 \mathrm{~d}$ & 1,60 \\
Persemaian RPH Garahan (KPH Jember) & 540 & $26,34 \mathrm{~d}$ & 1,69 \\
Pertanaman RPH Kemiri (KPH Pasuruan) & 700 & $29,69 \mathrm{c}$ & \\
\hline
\end{tabular}

Angka-angka yang diikuti oleh huruf yang sama pada kolom yang sama menunjukkan perbedaan pengaruh yang nyata berdasarkan uji Duncan taraf 5\%.

tahun 2013 yang belum ditanam di lapang pada akhir 2013 (Tabel 6) dan dipersiapkan untuk ditanam pada akhir tahun 2014 ketika musim hujan dimulai. Di lain pihak indeks penyakit di persemaian Pujon Selatan menunjukkan rerata tertinggi $(58,31)$. Jika dihubungkan dengan kinerja isolat Pujon Selatan yang ditunjukkan oleh indeks penyakit pada bibit sebesar 37,18 (Tabel 5), tampak terdapat perbedaan nilai indeks yang cukup besar. Hal ini diduga bibit produksi tahun 2013 di Pujon Selatan kurang mendapat perawatan yang optimal. Namun demikian isolat patogen di Pujon Selatan cukup virulen dan tidak dapat diabaikan dalam pengelolaan persemaian.

Pada daun pinus tanaman muda, tampaknya infeksi sekunder seperti yang ditunjukkan oleh Guyader et al. (2013) sebagai akibat overlapping daun pada kepadatan tajuk yang tinggi dan perkembangan keparahan penyakit sebagai akibat periode kebasahan daun (Moral et al., 2012), tidak terjadi secara efektif. Di lain pihak sejak umur bibit pinus 5-6 bulan aktivitas peroksidase rata-rata daun jarum, yang berperan dalam ketahanan tanaman, meningkat (Sutarman et al., 2004a) dibandingkan umur lebih muda.

Indeks penyakit pada pertanaman muda pinus di RPH Kemiri rata-rata sebesar 29,69; jika mengacu pada kriteria penentuan indeks penyakit yang ditunjukkan Sutarman et al. (2001) hal itu berarti bahwa bibit yang ditanam di lapangan bisa dipastikan hampir seluruhnya sudah terinfeksi di ujung-ujung daun jarumnya dengan status serangan bersifat ringan (atau rata-rata skor 1).

Meskipun secara keseluruhan indeks penyakit baik di persemaian maupun di pertanaman masih bersifat ringan sampai sedang, tapi seluruh bibit telah menjadi sumber bagi penularan penyakit pada saat itu dan pada tahun produksi berikutnya.

\section{SIMPULAN}

Patogen yang menyebabkan hawar daun bibit di sepuluh lokasi representasi geoekologi kawasan hutan pinus di Jawa Timur adalah jenis $P$. theae Sawada dengan indeks penyakit (skala 0-100) mencapai 7,3826,96 pada bibit berumur 2-6 bulan dan 28-31 pada tanaman umur 10 bulan di lapangan. Perbedaan ketinggian tempat tidak mempengaruhi perbedaan indeks penyakit. Bibit pinus yang terserang parah adalah di RPH Ngantang dan RPH Wagir dengan indeks penyakit (skala 0-100) 40,45 dan 50,33 sedangkan tanaman muda yang terserang parah adalah di persemaian RPH Wagir dan RPH Pujon Selatan dengan indeks penyakit (skala 0-100) 42,07 dan 58,31. Berdasarkan nilai indeks penyakit, 3 isolat patogen yang memerlukan perhatian serius adalah isolat Wagir $(985 \mathrm{~m} \mathrm{dpl})$ paling virulen, yang diikuti oleh Ngantang (500 m dpl), dan Pujon Selatan (1200 m dpl).

\section{SANWACANA}

Terima kasih disampaikan kepada Direktorat Jendral Pendidikan Tinggi Kementerian Pendidikan dan Kebudayaan atas dukungan pendanaan penelitian ini melalui skema Hibah Penelitian Fundamental Tahun 2014 serta Perum Perhutani Unit II Jawa Timur atas izin kegiatan penelitian dan dukungan segenap pelaksana manajemen di bawahnya hingga di lapangan. 


\section{DAFTAR PUSTAKA}

Achmad, Hadi S, Harran S, Sa'id EG, Satiawihardja B, \& Kardin MK. 1997. Biochemical defence of Pinus merkusii seedlings against damping-off pathogens. In: Kikkawa J, Dart P, Doley D, Ishii K, Lamb D, \& Suzuki K (Eds.). Proceedings of Brisbane Workshop. pp. 237-240. BIIOREFOR/IUFRO/SPDC, Brisbane, Australia.

Achmad, Hadi S, Herlinayana EN, \& Setiawan A. 1999a. Patogenisitas Rhizoctonia solani pada semai Pinus merkusii dan Acacia mangium. J. Man. Hut. Trop. V(1): 11-21.

Achmad, Hadi S, Sa' id EG, Satiawihardja B, Kardin MK, \& Harran S. 1999b. The potential use of two species of Trichoderma for the biological control of damping-off on Pinus merkusii. In: De la Cruz RE, Follosco M, \& Ishii K (Eds.). Proceedings of Manila Workshop. pp. 103107. BIIO-REFOR/IUFRO/SPDC, Manila, Philippines.

Canon P, Pascoe I, Beilharz \& Zuan ZQ. 1997. Report on fungi from diseased Acacia samples examined at Institute of Horticultural Development, Knoxfield, Victoria. In: Old KM, Lee SS, \& Sharma JK (Eds.). Proceedings of an International Workshops Subanjeriji (South Sumatra). Disease of Tropical Acacias. pp. 108-113. CIFOR Special Publication, Bogor, Indonesia. April 28-May 3, 1996.

Goss EM, Larsen M, Vercauteren A, Werres S, Heungens K, \& Grünwald NJ. 2011. Phytophthora ramorum in Canada: Evidence for migration within North America and from Europe. Phytopathology 101(1): 166-171.

Guyader S, Crombez J, Salles M, Bussière F, \& Bajazet T. 2013. Modelling the effects of temperature and leaf wetness on monocyclic infection in a tropical fungal pathosystem. Eur. J. Plant Pathol. 136(3): 535-545. DOI 10.1007/s10658013-0185-8.
Malcolm GM, Kuldau GA, Gugino BK, \& JiménezGasco MDM. 2013. Hidden host plant associations of soilborne fungal pathogens: An ecological perspective. Phytopathology 103(6): 538-544.

Moral J, Jurado-Bello J, Sánchez MI, de Oliveira R, \& Trapero A. 2012. Effect of temperature, wetness duration, and planting density on olive anthracnose caused by Colletotrichum spp. Phytopathology 102(10): 974-981.

Old KM, Hood IA, \& Yuan ZQ. 1997. Diseases of tropical acacias in Northern Queensland. In: Old KM, Lee SS, \& Sharma JK (Eds.). Proceedings of an International Workshops Subanjeriji (South Sumatra). Diseases of Tropical Acacias. pp. 1-22. CIFOR Special Publication, Bogor, Indonesia.

Santamaría O, Smith DR, \& Stanosz GR. 2011. Interaction between Diplodia pinea and $D$. scrobiculata in Red and Jack Pine seedlings. Phytopathology 101(3): 334-339.

Sharma JK \& Florence EJM. 1997. Fungal pathogens as a potential threat to tropical acacias: case study of India. In: Old KM, Lee SS, \& Sharma JK (Eds.). Proceedings of an International Workshops Subanjeriji (South Sumatra). Diseases of Tropical Acacias. pp. 70-107. CIFOR Special Publication, Bogor, Indonesia. April 28-May 3, 1996.

Sutarman, Achmad, \& Hadi S. 2001. Penyakit hawar daun bibit Pinus merkusii di pesemaian. $J$. Agritek 9(4): 1419-1427.

Sutarman, Hadi S, Saefuddin A, Achmad, \& Suryani A. 2004a. Epidemiologi hawar daun bibit Pinus merkusii yang disebabkan oleh Pestalotia theae. J. Man. Hut. Trop. X(1): 43-60.

Sutarman, Hadi S, Suryani A, Achmad, \& Saefuddin A. 2004b. Patogenesis hawar daun bibit Pinus merkusii yang disebabkan oleh Pestalotia theae di pesemaian. J. HPT Tropika 4(1): 32-41. 